\title{
Depression-Factors, Symptoms, Prevention and the Role of Open Journal of Depression
}

\author{
Stanislava Y. Stoyanova \\ South-West University “Neofit Rilski”, Blagoevgrad, Bulgaria \\ Email: avka@abv.bg
}

Received November $15^{\text {th }}$, 2013; revised December 26 $6^{\text {th }}$, 2013; accepted January $8^{\text {th }}, 2014$

\begin{abstract}
Copyright (c) 2014 Stanislava Y. Stoyanova. This is an open access article distributed under the Creative Commons Attribution License, which permits unrestricted use, distribution, and reproduction in any medium, provided the original work is properly cited. In accordance of the Creative Commons Attribution License all Copyrights (C) 2014 are reserved for SCIRP and the owner of the intellectual property Stanislava Y. Stoyanova. All Copyright $@ 2014$ are guarded by law and by SCIRP as a guardian.
\end{abstract}

The data for the spread of depression in several countries are presented. The differences in occurrence of depression among some social categories of population are discussed. The symptoms and the forms of depression are described in brief, as well as several factors contributing to depression. The role of Open Journal of Depression is related to some possibilities for coping with and preventing depression.

Keywords: Depression; Mood Disorders; Coping

\section{Introduction}

Human health is among the most important values in all societies (European Values Study Group and World Values Survey Association, 2011). That is why every striving for improvement of human health (including by means of study of depression) is respectable and highly estimated.

Depression is a kind of mood (affective) disorders. It could be mild, moderate or severe, recurrent (repeated), psychogenic or reactive (World Health Organization, 2010). There are some differential peculiarities in the forms and development of depression.

Depression is one of the most frequent diseases. It influences about 20 million Americans each year (National Institute of Mental Health, 2013; Mental Health America, 2013; University of Maryland Medical Center, 2011) and between 5\% - 10\% of the population in Brazil, Germany, and Turkey (Info Center for Mental Health, 2006). Its spread in the other countries is probably similar. More and more different groups in the societies suffer from depression. The age boundaries of this illness widen among the elderly people (Büchtemann et al., 2012; Bose \& Neelakandan, 2013; Wood et al., 2010) and youth (Tezvaran, Akan, \& Zahmaciog, 2012; Cole et al., 2012), but depression is more typical for the people advanced in age (about 50 years old) than for the young people (Wood et al., 2010; Patten, Gordon-Brown, \& Meadows, 2010). The representatives of different kinds of occupations also experience this disorder in some moment of their life-even the doctors (Galán-Rodas et al., 2011). Women suffer more by depression than men do (Büchtemann et al., 2012), but men commit a suicide at least three times more often than the women do and 2/3rds of the suicide acts are due to depression (Info Center for Mental Health, 2007b).

Depression is related to suicide ideas and attempts, to diminished efforts in work and study, to decreased interest in life, and other people. Depression changes a big part of human life.

There are some somatic, behavioural and emotional changes related to depression. The depressive person suffers from lowering of mood, sadness, anxiety, reduction of energy, decrease in activity, loss of appetite, weight loss or weight growth, changes in libido. Interest, concentration, and motivation are reduced, but helplessness and indecisiveness are increased. Tiredness after even minimum effort is common. Sleep is disturbed (the typical problem is waking earlier in the morning several hours before the usual time). Appetite is diminished. Self-esteem and self-confidence are reduced. Some ideas of guilt or worthlessness are often present, as well as feeling rejected and alone (World Health Organization, 2010; Info Center for Mental Health, 2006).

There are a lot of reasons for depression-unemployment, financial problems, social isolation, stress, crisis situations, conflicts with the relatives, friends, colleagues, and institutions, physiological and hormonal processes related to heredity, etc. (Izard, 1977: 272-289). Depression is even related to the season changes, especially to the spring and fall (Info Center for Mental Health, 2007a). Such events are inevitable and mainly uncontrollable in human life. Everyone has different tolerance to their occurrence, but the interaction of several factors often is crucial for development of depression. In many cases, the own efforts are not enough to overcome it.

High depression is associated with high maladaptive coping and low social support (Thorsteinsson, Ryan, \& Sveinbjornsdottir, 2013). The uncontrolled attempts to overcome depression could lead to some forms of drug abuse. That is why the role and assistance of psychologists, psychiatrists and other specialists is important in our society. The treatment of depression is complex. It includes some medicines, psychotherapy, and the possible changes of the way of life and the environment. 
Moderate physical activity is important in preventing depression and stress (Gavric, 2012).

Open Journal of Depression gives the possibility one to accumulate more knowledge about the reasons, the symptoms, the forms, and the treatment of this disease by means of assuring support and patience, encouraging the positive outcomes and doing the things that one likes.

Open Journal of Depression has the task to permit the expressions of sympathy, support and care for suffering people; to help the estimation of the degree of risk and the acceptance of situation; to offer different possibilities for solving the problem; to encourage and to spread knowledge, skills and experience.

Since its start in 2012, Open Journal of Depression has published several articles dealing with some aspects of depression - its treatment, measurement, and coping. The aim of Open Journal of Depression is to increase the number of the presented topics related to depression, the number of the co-operating authors and the own usefulness for the readers and specialists.

\section{REFERENCES}

Bose, P. C., \& Neelakandan, R. (2013). A study on hospital anxiety and depression among aged groups. Indian Streams Research Journal, 3, 1-4.

Büchtemann, D., Luppa, M., Bramesfeld, A., \& Riedel-Heller, S. (2012). Incidence of late-life depression: A systematic review. Journal of Affective Disorders, 142, 172-179. http://dx.doi.org/10.1016/j.jad.2012.05.010

Cole, D. A., Sun-Joo, C., Martin, N. C., March, J. S., Compas, B. E., Rohde, P., Essex, M. J., Curry, J. F., Slattery, M. J., Youngstrom, E. A., Findling, R. L., Goodyer, I. M., Weissman, M., Hyde, J. S., Forehand, R., Felton, J. W., \& Maxwell, M. A. (2012). Are Increased Weight and Appetite Useful Indicators of Depression in Children and Adolescents? Journal of Abnormal Psychology, 121, 838-851. http://dx.doi.org/10.1037/a0028175

European Values Study Group and World Values Survey Association. (2011). Values Surveys 1981-2004 Integrated Questionnaire v.20060423. http://www.wvsevsdb.com/wvs/WVSAnalize.jsp?Idioma=I

Galán-Rodas, E., Gálvez-Buccollini, J. A., Vega-Galdós, F., Osada, J., Guerrero-Padilla, D., Vega-Dienstmaier, J., Talledo, L., Catacora, M., \& Fiestas, F. (2011). Salud Mental en Médicos Que Realizan El Servicio Rural, Urbano-Marginal En Salud En El Perú: Un Estudio de
Línea Base. Revista Peruana Medicina Experimental Salud Publica, 28, 277-281. http://dx.doi.org/10.1590/S1726-46342011000200015

Gavric, Z. (2012). Determining the score for depression and its relationship with the level of physical activity in a patient at the family medicine. Open Journal of Depression, 1, 1-7. http://dx.doi.org/10.4236/ojd.2012.11001

Info Center for Mental Health (2006). Depresia [Depression]. http://mh-center.info/Files/Newsletter/Public/0e8ec3ec9012b3d2d11 7d736e713f649.pdf

Info Center for Mental Health (2007a). Bipoliarno Afektivno Razstroistvo [Bipolar affect Disorder].

http://mh-center.info/Files/Newsletter/Public/cf50a793e04776cf4b3f 6166648e117b.pdf

Info Center for Mental Health (2007b). Samoubiistvo [Suicide]. http://mh-center.info/Files/Newsletter/Public/732d6f0e91bb2855a54 cb5a0a6ab4cfa.pdf

Izard, C. E. (1977). Human emotions. New York: Plenum Press. http://dx.doi.org/10.1007/978-1-4899-2209-0

Mental Health America (2013). Depression: What you need to know. Clinical depression is a common, real and treatable illness. http://www.mentalhealthamerica.net/go/information/get-info/depress ion/depression-what-you-need-to-know

National Institute of Mental Health (2013). The numbers count: Mental disorders in America.

http://www.nimh.nih.gov/health/publications/the-numbers-count-me ntal-disorders-in-america/index.shtml

Patten, S. B., Gordon-Brown, L., \& Meadows, G. (2010). Simulation studies of age-specific lifetime major depression prevalence. BMC Psychiatry, 10, 85-100. http://dx.doi.org/10.1186/1471-244X-10-85

Thorsteinsson, E. B., Ryan, S. M., \& Sveinbjornsdottir, S. (2013). The mediating effects of social support and coping on the stress-depression relationship in rural and urban adolescents. Open Journal of Depression, 2, 1-6. http://dx.doi.org/10.4236/ojd.2013.21001

Tezvaran, Z., Akan, H., \& Zahmaciog, O. (2012). Risk of depression and anxiety in high school students and factors affecting it. Health MED, 6, 3333-3339.

University of Maryland Medical Center (2011). Depression. http://www.umm.edu/altmed/articles/depression-000047.htm

Wood, B. M., Nicholas, M. K., Blyth, F., Asghari, A., \& Gibson, S. (2010). The utility of the short version of the depression anxiety stress scales (DASS-21) in elderly patients with persistent pain: Does Age make a difference? Pain Medicine, 11, 1780-1790. http://dx.doi.org/10.1111/j.1526-4637.2010.01005.x

World Health Organization (2010). ICD-10. Version: 2010. http://apps.who.int/classifications/icd10/browse/2010/en\#/F32 